\title{
IL-15 deficiency promotes tumor growth in tax transgenic mice
}

\author{
Daniel Rauch, Sirosh Bokhari, John Harding, Lee Ratner* \\ From 15th International Conference on Human Retroviruses: HTLV and Related Viruses \\ Leuven and Gembloux, Belgium. 5-8 June 2011
}

IL-15 is an NFkB activated cytokine with structural similarity to IL-2 that has been implicated as a promoter of ATLL. Proposed mechanisms include; i) establishment of an autocrine loop in tumor cells that express both IL-15 and the IL-15 receptor, ii) IL-15 mediated protection from apoptosis, and iii) IL-15 mediated immune regulation that promotes tumor growth. IL-15 blockade is being considered as a therapeutic approach to HTLV-1 malignancies. To examine the effects of IL15 deficiency on HTLV-1 malignancy in vivo, we developed IL-15-/- TAX-LUC mice in which firefly luciferase under the HTLV-1 LTR serves as a reporter of Tax expression driven by the granzyme B promoter. Unexpectedly, the absence of IL-15 resulted in a significantly enhanced tumor phenotype in TAX-LUC mice which developed markedly larger, more numerous, and more aggressive tumors. IL-15 deficiency also resulted in severe osteolytic disease, platelet and bone marrow abnormalities. Administration of soluble IL-15 slowed tumor growth in vivo. Characteristics of cell lines derived from IL-15-/- Tax tumors were indistinguishable from tumor cells derived from IL-15+/+ Tax tumors. RNA harvested from malignant and infiltrating cells within tumors indicated that tumor immunity is significantly affected by IL-15 loss. NK and gamma-delta T cells are diminished in tumor infiltrates in the absence of IL-15 and the malignant cells express elevated levels of IL-1alpha. These findings reveal a profound of effect of tumor immunity in TAX malignancies, implicate IL1alpha as an important factor in the immune response to ATLL, and caution against IL-15 blockade as an ATLL therapy.

* Correspondence: Iratner@dom.wustl.edu

Division of Molecular Oncology, St Louis, MO, 63110, USA
Published: 6 June 2011

doi:10.1186/1742-4690-8-S1-A24

Cite this article as: Rauch et al.: IL-15 deficiency promotes tumor growth in tax transgenic mice. Retrovirology 2011 8(Suppl 1):A24.

Submit your next manuscript to BioMed Central and take full advantage of:

- Convenient online submission

- Thorough peer review

- No space constraints or color figure charges

- Immediate publication on acceptance

- Inclusion in PubMed, CAS, Scopus and Google Scholar

- Research which is freely available for redistribution

\section{Biomed Central}

